\title{
Heritable L1 retrotransposition in the mouse primordial germline and early embryo
}

\author{
Sandra R. Richardson, ${ }^{1}$ Patricia Gerdes, ${ }^{1}$ Daniel J. Gerhardt, ${ }^{1,2}$ \\ Francisco J. Sanchez-Luque, ${ }^{1,3}$ Gabriela-Oana Bodea, ${ }^{1}$ Martin Muñoz-Lopez, ${ }^{3}$ \\ J. Samuel Jesuadian, ${ }^{1}$ Marie-Jeanne H.C. Kempen, ${ }^{1}$ Patricia E. Carreira, ${ }^{1}$ \\ Jeffrey A. Jeddeloh, ${ }^{4}$ Jose L. Garcia-Perez, ${ }^{3,5}$ Haig H. Kazazian Jr., ${ }^{6}$ Adam D. Ewing, ${ }^{1}$ \\ and Geoffrey J. Faulkner ${ }^{1,7,8}$
}

\begin{abstract}
${ }^{1}$ Mater Research Institute-University of Queensland, Woolloongabba QLD 4102, Australia; ${ }^{2}$ Invenra, Incorporated, Madison, Wisconsin 53719, USA; ${ }^{3}$ Department of Genomic Medicine, GENYO, Centre for Genomics and Oncological Research, PfizerUniversity of Granada-Andalusian Regional Government, PTS Granada, 18016 Granada, Spain; ${ }^{4}$ Roche Sequencing Solutions, Incorporated, Madison, Wisconsin 53719, USA; ${ }^{5}$ Medical Research Council Human Genetics Unit, Institute of Genetics and Molecular Medicine, University of Edinburgh, Western General Hospital, Edinburgh EH4 2XU, United Kingdom; ${ }^{6}$ Institute of Genetic Medicine and Department of Pediatrics, Johns Hopkins University School of Medicine, Baltimore, Maryland 21205, USA; ${ }^{7}$ School of Biomedical Sciences, ${ }^{8}$ Queensland Brain Institute, University of Queensland, Brisbane QLD 4072, Australia
\end{abstract}

\begin{abstract}
LINE-1 (L1) retrotransposons are a noted source of genetic diversity and disease in mammals. To expand its genomic footprint, L1 must mobilize in cells that will contribute their genetic material to subsequent generations. Heritable L1 insertions may therefore arise in germ cells and in pluripotent embryonic cells, prior to germline specification, yet the frequency and predominant developmental timing of such events remain unclear. Here, we applied mouse retrotransposon capture sequencing (mRC-seq) and whole-genome sequencing (WGS) to pedigrees of C57BL/6] animals, and uncovered an L1 insertion rate of $\geq 1$ event per eight births. We traced heritable $\mathrm{Ll}$ insertions to pluripotent embryonic cells and, strikingly, to early primordial germ cells (PGCs). New L1 insertions bore structural hallmarks of target-site primed reverse transcription (TPRT) and mobilized efficiently in a cultured cell retrotransposition assay. Together, our results highlight the rate and evolutionary impact of heritable $\mathrm{L} 1$ retrotransposition and reveal retrotransposition-mediated genomic diversification as a fundamental property of pluripotent embryonic cells in vivo.
\end{abstract}

[Supplemental material is available for this article.]

Long interspersed element 1 (LINE-1 or L1) is a mobile genetic element active in nearly all mammals (Furano 2000). L1 sequences mobilize via a copy-and-paste mechanism, termed retrotransposition (Moran et al. 1996), and comprise $~ 18 \%$ of mouse DNA (Waterston et al. 2002). Each mouse genome harbors 3000 fulllength retrotransposition-competent L1s (RC-L1s) belonging to three $\mathrm{L} 1$ subfamilies ( $T_{F}, G_{F}$, and $A$ ) as well as nearly 600,000 L1 copies rendered immobile by $5^{\prime}$ truncation and the accumulation of internal mutations (Fanning 1983; Loeb et al. 1986; Padgett et al. 1988; Kingsmore et al. 1994; Takahara et al. 1996; DeBerardinis et al. 1998; Naas et al. 1998; Goodier et al. 2001; Waterston et al. 2002; Sookdeo et al. 2013). The ongoing production of new, heritable RC-L1 copies is therefore essential to preserve L1 mobility over evolutionary time. It follows that L1 mRNA and protein are expressed during germline and early embryonic development (Martin and Branciforte 1993; Branciforte and Martin 1994; Trelogan and Martin 1995; Garcia-Perez et al. 2007; Soper et al. 2008; Malki et al. 2014), and numerous host mechanisms regulate L1 activity during these stages (Yoder et al. 1997; Bourc'his and

\footnotetext{
Corresponding authors: sandra.richardson@mater.uq.edu.au, faulknergj@gmail.com

Article published online before print. Article, supplemental material, and publication date are at http://www.genome.org/cgi/doi/10.1101/gr.219022.116.
} Freely available online through the Genome Research Open Access option.
Bestor 2004; Watanabe et al. 2006, 2008; Aravin et al. 2008; Soper et al. 2008; Rowe et al. 2010; Zamudio and Bourc'his 2010; Wissing et al. 2011; Castro-Diaz et al. 2014; Crichton et al. 2014).

The developmental timing of only two heritable human L1 insertions has been elucidated; one event likely occurred in the female germline (Brouha et al. 2002), and the other occurred in a pluripotent embryonic cell and resulted in maternal somatic and germline mosaicism (van den Hurk et al. 2007). This result is consistent with reports of L1 retrotransposition in cultured human embryonic stem cells and induced pluripotent stem cells (iPSCs) (Garcia-Perez et al. 2007; Wissing et al. 2012; Klawitter et al. 2016), although a study of mouse iPSCs revealed little endogenous retroelement activity (Quinlan et al. 2011). Studies of transgenic L1 reporter animals have demonstrated retrotransposition in the germline (Ostertag et al. 2002; An et al. 2006) and in the early embryo (Kano et al. 2009). Surprisingly, in the latter study, transmission of engineered L1 insertions from mosaic parental animals to offspring was never observed, suggesting somatic but not germline contribution of insertion-harboring embryonic cells (Kano et al. 2009). Overall, the frequency and developmental timing of heritable L1 retrotransposition in vivo remain unclear. Here, we overcome the rarity of phenotype-causing endogenous

(C) 2017 Richardson et al. This article, published in Genome Research, is available under a Creative Commons License (Attribution 4.0 International), as described at http://creativecommons.org/licenses/by/4.0/. 
retrotransposition events, and avoid the caveats of transgenic model systems, by adapting retrotransposon capture sequencing (RC-seq) (Baillie et al. 2011; Shukla et al. 2013) to detect the following presently active mouse endogenous retrotransposons: $T_{F}, G_{F}$, and A subfamily L1 elements, B1 and B2 SINEs, and IAP and ETn long terminal repeat (LTR) elements (mRC-seq) (Supplemental Fig. S1A; Mager and Stoye 2015; Richardson et al. 2015). We apply this technology to pedigrees of wild-type C57BL/6J mice to investigate the rate and developmental timing of heritable L1 insertions.

\section{Results}

We bred two- and three-generation pedigrees of C57BL/6J mice (Fig. 1), a strain known to accommodate recent L1 activity (Akagi et al. 2008), and used mRC-seq and whole-genome sequencing (WGS) to identify retrotransposon insertions absent from the C57BL/6J reference genome and not previously identified in an extensive analysis of polymorphic transposable element insertions across 13 commonly used inbred and four wild-derived mouse strains (Fig. 1; Supplemental Fig. S1; Methods; Nellaker et al. 2012). After sequencing analyses, we classified $28 \mathrm{~L} 1$ and short interspersed element (SINE) insertions present in at least one of the six "P-generation" animals (SRA/SRB, SRC/SRD, SRE/SRF) and absent from the $\mathrm{C} 57 \mathrm{BL} / 6 \mathrm{~J}$ reference genome as polymorphic. Each "P-generation" animal harbored an overlapping subset of 17-19 polymorphic insertions; the specific polymorphic insertion content of each animal in the study can be found in Supplemental Table 2. Transmission of differentially present/absent polymorphic insertions was consistent with the known relationships among mice in our study (Fig. 1; Supplemental Table 2). Using data from mRC-seq reads and PCR validation followed by capillary sequencing, we discerned the complete structures of 17 polymorphic insertions (Supplemental Fig. S3; Supplemental Tables 2, 3), comprising $11 \mathrm{~L} 1 \mathrm{~T}_{\mathrm{F}}$ subfamily insertions, two B1 SINEs, and four B2 SINEs. Despite efficient detection of reference IAP and ETn retrotransposons (Supplemental Fig. S1C), we identified no polymorphic LTR insertions in our mice. This result may reflect differences in the activity levels of retrotransposon families among inbred mouse strains, revealed by numerous recent studies (Akagi et al. 2008, 2010; Quinlan et al. 2010; Keane et al. 2011; Li et al. 2012; Nellaker et al. 2012). For example, the majority of previously identified de novo IAP insertions arose on the I $\Delta 1$ subtype of the $\mathrm{C} 3 \mathrm{H} / \mathrm{HeJ}$ mouse strain (Maksakova et al. 2006).

We regarded insertions detected in one or more offspring but absent from the corresponding parents as potentially de novo (Supplemental Fig. S1B). Using PCR and capillary sequencing, we validated 11 de novo L1 insertions (Table 1; Supplemental Table 2). All 11 were $T_{F}$ subfamily elements, consistent with previous reports of disease-causing L1 insertions in mice wherein all insertions for which sufficient L1 sequence was present for subfamily distinction were identified as $\mathrm{T}_{\mathrm{F}}$ elements (Kingsmore et al. 1994; Mulhardt et al. 1994; Kohrman et al. 1996; Takahara et al. 1996; Perou et al. 1997; Naas et al. 1998; Yajima et al. 1999; Cunliffe et al. 2001). De novo L1 insertions bore hallmarks of L1 retrotransposition by target-primed reverse transcription (TPRT), including insertion at sequences resembling the $\mathrm{L} 1$ endonuclease cleavage motif ( $5^{\prime}$-TTTT/AA-3'), the presence of 13- to 17-bp target-site duplications (TSDs), and 3' poly(A) tracts (Table 1; Supplemental Figs. S1E, S4; Singer et al. 1983; Scott et al. 1987; Luan et al. 1993; Moran et al. 1996; Jurka 1997). The average GC content of de novo L1 insertion sites within a 50-bp and 20-kb window of the en- donuclease cleavage position was 30\% and 38\%, respectively, consistent with a previously described preference of L1 for AT-rich regions (Supplemental Table 4; Szak et al. 2002; Boissinot et al. 2004; Gasior et al. 2007). One insertion (insertion \#5) (Fig. 3A, below) landed within the gene Ano4, which encodes a brain-expressed transmembrane protein of unknown function (Picollo et al. 2015; Petryszak et al. 2016). Consistent with the observation that intronic L1 insertions in antisense orientation have little impact on RNA polymerase processivity (Han et al. 2004), we did not observe a decrease in Ano4 mRNA levels in forebrain of animals heterozygous for this insertion (Supplemental Fig. S1G). Insertion \#5 also occurred within an intronic L1mA5 element, and two additional intergenic insertions landed within existing L1 repeats (Supplemental Table 4).

All 11 de novo insertions were $5^{\prime}$ detected by mRC-seq and thus full-length (containing $\geq 1 \mathrm{~T}_{\mathrm{F}}$ monomer), reflecting depletion of mouse L1 3' termini observed during Illumina sequencing (Supplemental Fig. S1D; Supplemental Tables 1, 2), possibly due to the GC-rich nature of the mouse L1 $3^{\prime}$ end sequence (Chambers et al. 2015). Furthermore, the de novo L1 insertions had relatively long poly(A) tracts (average $\sim 64 \mathrm{bp}$ ), reducing the likelihood that L1 $3^{\prime}$ end sequence and flanking genomic DNA would be captured in a single sequencing read. However, 20-30x WGS, which, in principle, could allow detection of the $5^{\prime}$ junctions of $5^{\prime}$ truncated L1 insertions, applied to nine mouse genomes (SRE, SRF, and offspring SREF15-21) uncovered no 5' truncated de novo L1 insertions (Fig. 1; Supplemental Tables 1, 2), and a previous analysis suggested that $\mathrm{T}_{\mathrm{F}} \mathrm{L} 1 \mathrm{~s}$ undergo $5^{\prime}$ truncation less frequently than other L1 elements (Hardies et al. 2000). Complete internal sequencing of nine de novo L1 insertions revealed intact ORFs and the absence of mutations in critical functional domain residues (Supplemental Fig. S2; Furano 2000).

Next, we used PCR genotyping to investigate the developmental origin of each de novo L1 insertion (Supplemental Fig. $\mathrm{S} 1 \mathrm{~B})$. Insertions \#1 and \#2 were identified by $\mathrm{mRC}$-seq in mice SRAB2 and SRAB15, respectively (Fig. 2A; Supplemental Fig. S5A; Supplemental Table 2). We did not detect these insertions by PCR genotyping in the somatic tissues of parental mice SRA and SRB; however, insertions \#1 and \#2 were detected by PCR in both testicles of paternal mouse SRB (Fig. 2A; Supplemental Fig. $\mathrm{S} 5 \mathrm{~A}$ ). Inheritance of each insertion by only $1 / 20$ offspring, coupled with their presence in both testicles of the paternal mouse, suggested germline-restricted mosaicism for insertions \#1 and \#2 in mouse SRB (Fig. 2B; Supplemental Fig. S5A).

In an inverse approach to identify germline-restricted mosaic insertions, we performed deep ( 260x) mRC-seq on the germ cell fraction of each testicle of mouse SRCD14. We detected and PCRvalidated insertion \#7 in both testicles and did not detect it in the somatic tissues of SRCD14 (Fig. 2C,D; Supplemental Table 2). An insertion-specific genomic DNA qPCR assay targeting the 5' L1genome junction of insertion \#7 revealed its prevalence of $\sim 11 \%$ and $\sim 4 \%$ in the germ cell fraction of the left and right testicle of SRCD14, respectively (Fig. 2E), and subsequent PCR genotyping demonstrated transmission of the insertion to 2/65 progeny of SRCD14 (F2-7 and F2-55) (Fig. 1; Supplemental Fig. $\mathrm{S} 5 \mathrm{~B})$. As evidenced by our failure to detect L1 insertions \#1, \#2, and \#7 from mesoderm-, ectoderm-, and endoderm-derived tissues of the respective paternal mice, we reasoned that these insertions likely arose in early primordial germ cells (PGCs) during paternal embryonic development, prior to PGC colonization of the genital ridge and the formation of the testes. Thus, we conclude that L1 retrotransposition can occur in early PGCs, resulting

\section{Genome Research}

www.genome.org 


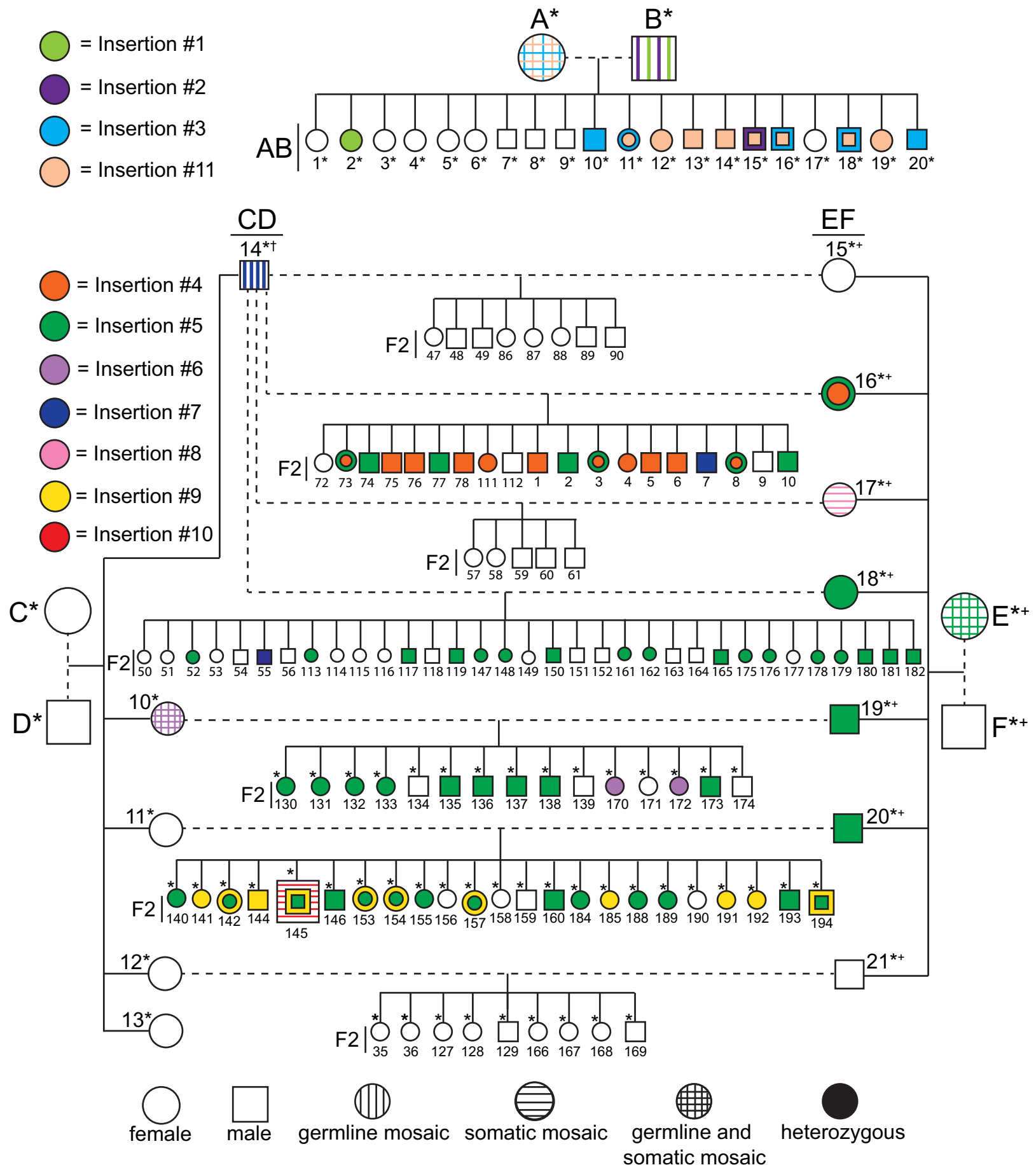

$\left({ }^{*}\right)$ Somatic tissues assayed by mRC-seq $\quad(\dagger)$ Germ cells assayed by $\mathrm{mRC}$-seq

$(+)$ Somatic tissues assayed by WGS

Figure 1. Origin and transmission of de novo $L 1$ insertions in mouse pedigrees. Above, two-generation pedigree originating from parental mice SRA/SRB. Below, three-generation pedigrees originating from parental mice SRC/SRD and SRE/SRF. F1 animals are designated by the parental pair from which they arose (AB, CD, EF); F2 animals are so indicated. De novo L1 $\mathrm{T}_{\mathrm{F}}$ insertions \#1-\#11 are color coded. In subsequent figures, schematics of each insertion are likewise color coded. With respect to each insertion, filled shapes indicate heterozygous animals, vertical hatching indicates germline mosaicism, horizontal hatching indicates somatic mosaicism, and vertical and horizontal hatching together indicates both somatic and germline mosaicism. Circles represent female animals; squares represent males. Dashed lines indicate matings. Animals for which mRC-seq was performed on somatic tissue gDNA are indicated with an asterisk; animals for which whole-genome sequencing (WGS) was performed on somatic tissue gDNA are indicated with a plus sign. For mouse SRCD14, mRC-seq was performed on somatic tissues as well as the germ cell fraction of the left and right testicles. Polymorphic retrotransposon insertions are not depicted in this figure. 
Table 1. Characteristics of 11 de novo L1 insertions identified in this study

\begin{tabular}{|c|c|c|c|c|c|c|c|}
\hline Insertion \# & Location $T_{F}$ & Monomers & Cleavage & TSD (bp) & $\operatorname{Poly}(A)(b p)$ & Developmental origin & Transmission \\
\hline 1 & $12 q$ & 3.5 & $\mathrm{TCTT} / \mathrm{AG}$ & 16 & $\sim 100$ & Male primordial germline & $1 / 20(5 \%)$ \\
\hline 2 & $2 q$ & 1.5 & TTTT/AA & 16 & $\sim 22^{*}$ & Male primordial germline & $1 / 20(5 \%)$ \\
\hline 3 & $10 \mathrm{q}$ & 3.5 & TTTT/AA & 16 & $\sim 100$ & Female early embryo & $5 / 20(25 \%)$ \\
\hline 4 & $3 q$ & 4 & TCTT/AT & 16 & $\sim 120$ & Late germline & $11 / 19(58 \%)$ \\
\hline 5 & $10 q$ & 5 & TCTT/GT & 14 & $\sim 39^{*}$ & Female early embryo & $4 / 7(57 \%)$ \\
\hline 6 & $14 q$ & 2.5 & $\mathrm{TCTT} / \mathrm{AC}$ & 17 & $\sim 30$ & Female early embryo & $2 / 15(13 \%)$ \\
\hline 7 & $18 q$ & 2.5 & TTGT/AA & 15 & $\sim 40^{*}$ & Male primordial germline & $2 / 65(3 \%)$ \\
\hline 8 & $17 q$ & 3 & CTTC/AA & 13 & $\sim 55$ & Female early embryo & $0 / 5(0 \%)$ \\
\hline 9 & $2 q$ & 4.5 & TGTT/AT & 15 & $\sim 40$ & Late germline & $11 / 23(48 \%)$ \\
\hline 10 & $3 q$ & 4.5 & TTAT/GT & 13 & $\sim 60$ & Male early embryo & $0 / 6(0 \%)$ \\
\hline 11 & $8 q$ & 4.5 & TCTT/AA & 14 & $\sim 100$ & Female early embryo & $8 / 20(40 \%)$ \\
\hline
\end{tabular}

All insertions are $L 1 T_{F}$ elements. ( $T_{F}$ monomers) Number of repetitive promoter units contained by each insertion. Cleavage indicates the L1 endonuclease cleavage motif, shown $5^{\prime}$ to $3^{\prime}$, (TSD) target-site duplication length, (Poly[A]) poly(A) tract length. Poly(A) tract lengths were determined by capillary sequencing and should be regarded as estimates. Insertions marked with an asterisk contain a $3^{\prime}$ transduction (see Supplemental Figs. S4, S8 for details). For each insertion, the deduced developmental origin and the frequency of transmission (i.e., the percentage of siblings heterozygous for the insertion) are indicated.

in germline-restricted genetic mosaicism and heritable de novo L1 insertions.

To investigate the capacity of de novo L1 insertions for subsequent retrotransposition, we cloned insertions \#1 and \#7 and tested their activity in a cultured cell retrotransposition assay (Fig. 2F; Moran et al. 1996; Wei et al. 2000). In HeLa cells, insertion \#1 and insertion \#7 jumped to $\sim 97 \%$ and $~ 205 \%$ efficiency, respectively, relative to $\mathrm{L} 1_{\mathrm{spa}}$, a previously identified disease causing $\mathrm{T}_{\mathrm{F}}$ insertion (Fig. 2G,H; Kingsmore et al. 1994; Mulhardt et al. 1994; Naas et al. 1998). Thus, consistent with previous reports (Naas et al. 1998; Kimberland et al. 1999), de novo L1 insertions are not only heritable but also have the potential to serve as progenitor elements for subsequent retrotransposition events.

We traced the developmental timing of six de novo L1 insertions to the early embryo. As an illustrative example, insertion \#5 was detected by $\mathrm{mRC}$-seq with a single sequencing read in the brain of maternal mouse SRE and robustly detected in 4/7 offspring (Fig. 1; Supplemental Table 2). PCR genotyping revealed bands of varying intensity among the somatic tissues and ovaries of mouse SRE (Fig. 3A,B), and by genomic DNA qPCR, the prevalence of insertion \#5 ranged from $\sim 0.2 \%$ in brain to $\sim 1.5 \%$ in the right ovary (Fig. 3C). Similarly, insertions \#3 (Supplemental Fig. S6A,B), \#6 (Supplemental Fig. S6C,D), and \#11 (Supplemental Fig. S6E) were each identified by mRC-seq in multiple offspring and genotyped as mosaic in the respective maternal tissues. Insertions \#8 (Supplemental Fig. S6F) and \#10 (Supplemental Fig. S6G) were identified by mRC-seq and were confirmed as mosaic in the tissues of mouse SREF17 and mouse F2145 , respectively, but were not transmitted to the limited offspring produced by these animals (five and six progeny, respectively) (Supplemental Fig. S6F,G). Therefore, we can neither confirm nor rule out the contribution of insertions \#8 and \#10 to the germ lineage. Taken together and consistent with previous studies (Garcia-Perez et al. 2007; van den Hurk et al. 2007; Kano et al. 2009; Wissing et al. 2012; Klawitter et al. 2016), our results demonstrate that L1 retrotransposition occurs in pluripotent cells of the early embryo, generates somatic and germline genetic mosaicism, and can give rise to heritable de novo L1 insertions.

Of the remaining two de novo L1 insertions, insertion \#4 likely represented a late germline event. This insertion was identified by mRC-seq in mouse SREF16, one of seven offspring of parental mice SRE and SRF, but was not detected in somatic and germ tissues of SRE or SRF (Fig. 4A,B; Supplemental Table 2). Upon crossing mouse SREF16 to mouse SRCD14, insertion \#4 was transmitted to 11/19 offspring (Figs. 1, 4B), consistent with mouse SREF16 being either consummately heterozygous for the insertion or mosaic with a high degree of germline prevalence. To distinguish these possibilities, we used a 5' L1-genome junction qPCR assay for insertion \#4, with heterozygous and wild-type F2 offspring as controls, and found that SREF16 contained $\sim 1$ copy each of insertion \#4 and the genomic empty site across all tissues tested (Fig. 4C,D). Insertion \#4 could not be detected in the gonads of SRE or SRF, despite sensitivity of the qPCR assay to $0.1 \%$ prevalence (Supplemental Fig. S7A). We therefore conclude that mouse SREF16 was heterozygous for insertion \#4 and that this insertion arose sufficiently late during germline development of parental mouse SRE or SRF to preclude its detection in bulk gonad tissues, or possibly post-conception in SREF16 at the mature zygote stage.

Finally, insertion \#9 was detected in 11/23 offspring of SRCD11 and SREF20 (Fig. 1; Supplemental Fig. S7B,C; Supplemental Table 2). This rate of transmission suggested either parental heterozygosity or mosaicism with a high degree of germline prevalence. However, we could not detect insertion \#9 by nested PCR in the gonads of SRCD11 or SREF20 (Supplemental Fig. $\mathrm{S} 7 \mathrm{H})$. The developmental origins of insertion \#9 are therefore unclear. We speculate that this event was germline-restricted mosaic in SRCD11 or SREF20, but that the subset of germ cells carrying insertion \#9 was depleted by the time the gonads of these animals were harvested, at age 39 and $40 \mathrm{wk}$ (Lei and Spradling 2013).

We next sought to identify the progenitor L1 elements responsible for heritable de novo insertions. During transcription of an RC-L1 element, the native L1 polyadenylation signal is occasionally bypassed in favor of a downstream genomic polyadenylation signal, and upon retrotransposition the nascent L1 insertion incorporates a genomic sequence tag, or $3^{\prime}$ transduction, that identifies the progenitor L1 element (Holmes et al. 1994; Moran et al. 1996, 1999; Goodier et al. 2000; Pickeral et al. 2000; Macfarlane et al. 2013). Two early PGC insertions (\#2 and \#7) (Fig. 2C; Supplemental Fig. S8A,C), one early embryonic insertion (\#5) (Supplemental Fig. S8B), and two presumably recent polymorphic $\mathrm{L} 1 \mathrm{~T}_{\mathrm{F}}$ insertions differentially present/absent among our animals (Poly_L1T $\mathrm{F}_{-} 3$ and Poly_L1T $\mathrm{F}_{\mathrm{F}} 4$ ) (Table 1; Supplemental Table 2; Supplemental Figs. S3, S8D,E) carried 3' transductions, implicating five distinct full-length $\mathrm{L} 1 \mathrm{~T}_{\mathrm{F}}$ elements present in the $\mathrm{C} 57 \mathrm{BL} / 6 \mathrm{~J}$ reference genome. Thus, we have identified progenitor elements responsible for de novo heritable L1 insertions.

\section{Genome Research}

www.genome.org 
A

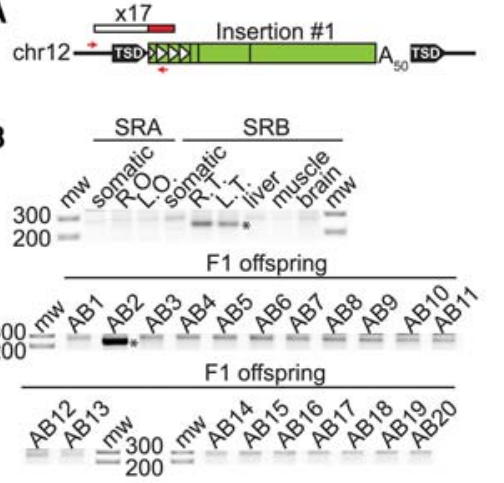

E
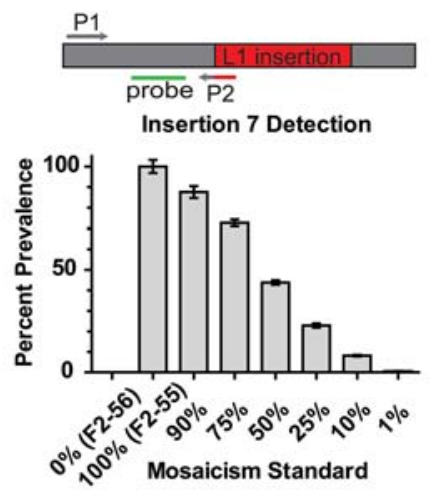

$\mathbf{F}$

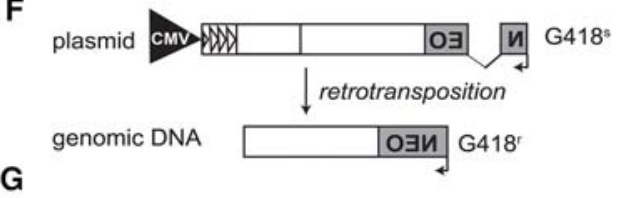

HeLa-JVM cells, $2 \times 10^{4}$ cells/well
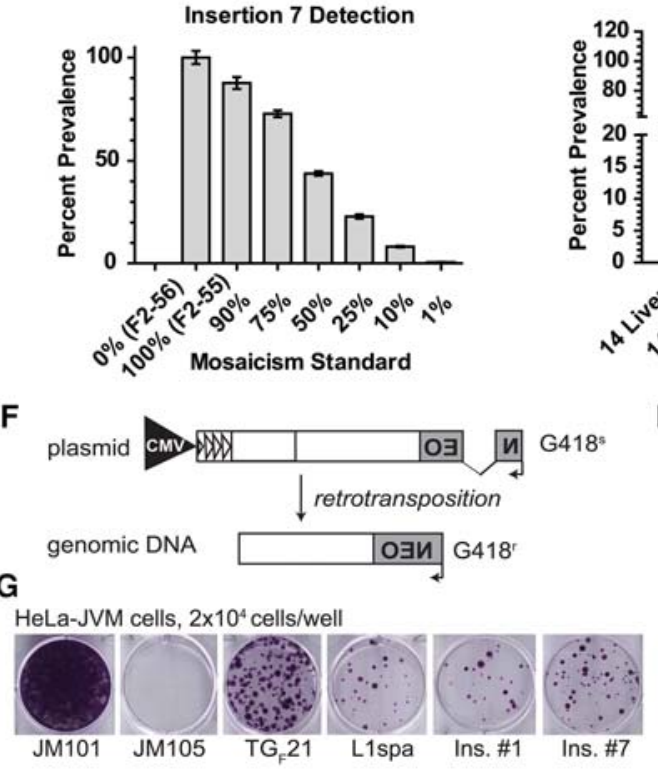

Insertion 7 Prevalence

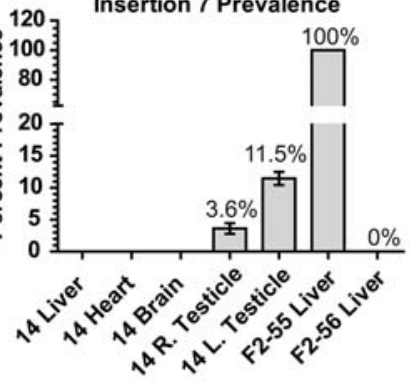

H

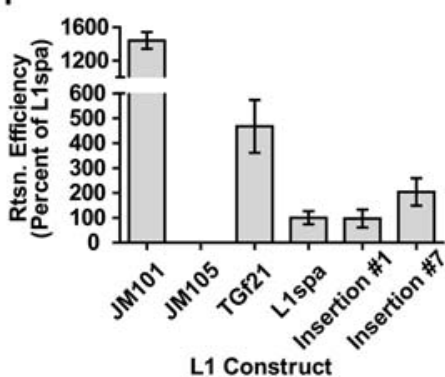

Figure 2. Retrotransposition and the generation of new active L1 copies in primordial germ cells. (A) Schematic of insertion \#1. Red/white rectangle indicates $\mathrm{mRC}$-seq reads. Red arrows indicate PCR primers used for genotyping. Triangles within the L1 5' UTR represent $T_{F}$ monomer units. $\left(A_{n}\right)$ poly $(A)$ tract, (TSD) target-site duplication. (B) Genotyping panel for insertion \#1. SRA (maternal) and SRB (paternal) tissues are indicated. (Somatic) Mix of liver, skeletal muscle, and brain genomic DNA; (R.O., L.O.) right ovary, left ovary; (R.T. and L.T.) right testicle, left testicle. F1 offspring of SRA and SRB (SRAB 1-20) were analyzed. Genotyping PCR was performed on liver gDNA for SRAB 1-9 and on whole embryo gDNA for SRAB 10-20. Here and in all subsequent figures, the validation product is marked with an asterisk. (C) Schematic of insertion \#7 and its donor element on Chr 6. Features are annotated as in A; an 84-bp 3' transduction of gDNA downstream of the Chr 6 donor element is represented in gray. The position of the donor element within the first intron of the gene Suclg2 on Chr 6 is shown. (D) $5^{\prime}$ junction PCR validation for insertion \#7. (E) A quantitative PCR (qPCR) assay for the prevalence of insertion \#7. A forward primer ( $P 1$, gray) is situated within flanking genomic DNA, and a reverse primer ( $P 2$, gray/red) spans the junction between the $5^{\prime}$ end of the L1 and the genomic sequence. A hydrolysis probe (green) is situated within genomic sequence adjacent to the reverse primer and on the same strand. Bottom, left: the qPCR assay can detect mosaicism for insertion \#7. The $x$-axis indicates the mosaicism standard used. The $y$-axis and percentages above each bar show detected percent prevalence, with the heterozygous animal set to $100 \%$. Data are reported as the mean and standard deviation of four technical replicates per reaction. At right, the GPCR assay applied to somatic tissues ( $x$-axis) and the germ cell fraction from the right and left testicles of SRCD14. Data are reported as the mean and standard deviation of three independent qPCR experiments, each comprising four technical replicates per reaction. ( $F$ ) Rationale of the cultured cell retrotransposition assay (Moran et al. 1996; Wei et al. 2000). (G) Retrotransposition assay in human HeLaJVM cells for insertion \#1 and insertion \#7. JM101 is a retrotransposition-competent human L1 (L1.3); JM105 is a negative control, consisting of L1.3 with a reverse transcriptase active site mutation. $\mathrm{TG}_{\mathrm{F}} 21$ is an active $G_{F}$ subfamily mouse $L 1 ; L 1_{\text {spa }}$ is an active $T_{F}$ subfamily mouse $L 1$. Colony formation indicates a successful retrotransposition event. $(H)$ Quantification of the retrotransposition assay. $\mathrm{L} 1_{\text {spa }}$ retrotransposition efficiency is set to $100 \%$. Data are reported as the mean and standard deviation of three independent experiments (biological replicates), each of which comprised three technical replicates.

Having observed transmission of germline-restricted and somatic/germline mosaic insertions in mouse, consistent with previous studies of human patients (Brouha et al. 2002; van den Hurk et al. 2007), we next investigated a previously reported mutagenic human L1 insertion for which the developmental timing had not been resolved. The $\mathrm{JH}-27$ insertion, which occurred in exon 14 of the Factor VIII gene, was identified in 1988 as the causative mutation in a case of noninherited hemophilia and was the first such example exhibiting L1 mobility in modern humans (Supplemental Fig. S9A; Kazazian et al. 1988). We performed a $5^{\prime}$ junction nested PCR (55 total cycles) specific for the JH-27 insertion on blood genomic DNA from the afflicted patient and his mother, with paternal DNA serving as a negative control. While a robust PCR product was detected in the patient DNA, the JH-27 insertion could not be detected in the maternal sample (Supplemental Fig. S9B). Given our mouse data indicating each heritable early embryonic L1 insertion was detectable in tissues derived from all three germ layers (Fig. 3; Supplemental Fig. S6), we suggest that insertion $\mathrm{JH}-27$ was very likely maternal germline-restricted.

\section{Discussion}

We uncovered 11 de novo L1 insertions among 85 mouse genomes, providing an estimate of one new insertion per eight mice $(11 / 85=0.13$ or $\sim 1 / 8)$. This figure is consistent with but more conservative than previous estimations that a new L1 insertion may arise in every two to three mice (Kazazian and Moran 1998; Kazazian 2000) and is much higher than estimates of one new L1 insertion per 100 live births in humans (Hancks and Kazazian 2012). Indeed, the technical hurdles limiting detection of 3' L1-genome junctions may have precluded identification of additional, $5^{\prime}$ truncated de novo L1 insertions in our pedigrees. Furthermore, while 85 genomes constitute the largest cohort of individual mice examined for de novo L1 insertions to date, future examination of more animals may allow fine-tuning of this rate estimate. The structure of our breeding pedigrees allowed us to observe the transmission of two new L1 insertions, \#4 and \#5, from heterozygous animals to their offspring (Fig. 1). We found that transmission of these insertions to 58\% and $52 \%$ of offspring, respectively, was not 
A

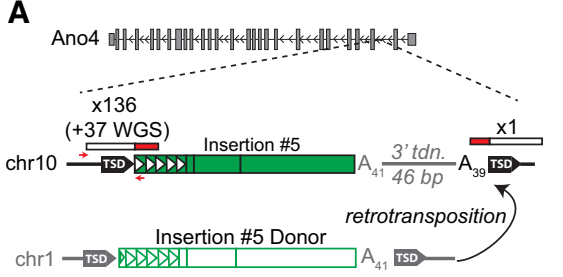

B

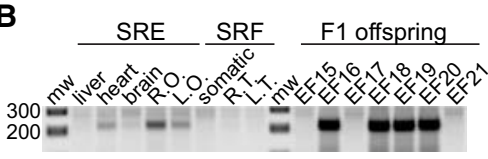

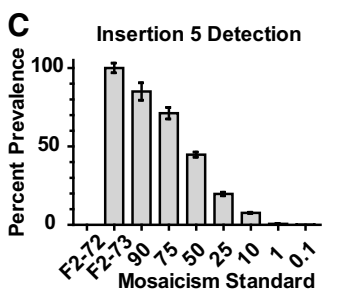

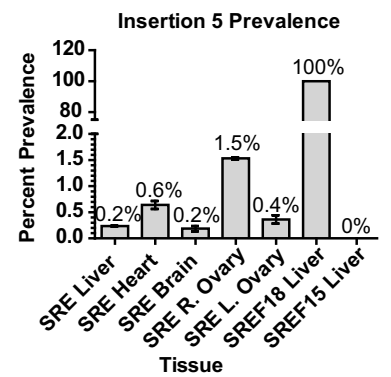

Figure 3. Retrotransposition in the early embryo. ( $A$ ) Schematic of insertion \#5 in the antisense orientation within the second intron of the gene Ano4 on Chr 10, and the donor element of insertion \#5 on Chr 1. Features are annotated as in Figure 2A. (B) Genotyping panel for insertion \#5. SRE (maternal) and SRF (paternal) tissues are indicated. (Somatic) Mix of liver, heart, and brain genomic DNA; (R.O., L.O.) right ovary, left ovary; (R.T., L.T.) right testicle, left testicle. (C) Top: Control assay demonstrating the ability of the qPCR assay to detect mosaicism for insertion \#5. Data are reported as the mean and standard deviation of four technical replicates per reaction. Bottom: Prevalence of insertion \#5 among the tissues of maternal mouse SRE. Liver genomic DNA from mouse SREF18, a heterozygote for insertion \#5, is set to $100 \%$. Mouse SREF15, which lacks insertion \#5, is included as a negative control. Data are reported as the mean and standard deviation of three independent qPCR experiments, each comprising four technical replicates per reaction.

significantly different from the expected transmission rate of $50 \%\left(\chi^{2}\right.$ test with one degree of freedom, two-tailed $P$ values of 0.49 and 0.67 , respectively). Thus, as expected, within a single generation we observe no evidence for positive or negative selection on a de novo L1 insertion. However, future studies tracking the transmission of de novo L1 insertions through many generations may reveal evidence for selection on particular insertions, perhaps dependent on their genomic locations and functional consequences.

We established for the first time that heritable endogenous L1 retrotransposition events arise in early PGCs, before the PIWI/piRNA retrotransposon defense pathway becomes active in male embryonic gonads (Aravin et al. 2008), resulting in germline-restricted genetic mosaicism (Fig. 5A). Alternatively, it is possible that these insertions arose earlier during embryonic development, in cells of the primitive ectoderm that had been set aside for the germline and did not contribute to the somatic lineages (Soriano and Jaenisch 1986). It is worth noting that all three de novo insertions traced to early PGCs occurred in male mice. This correlation may stem from the relatively small number of insertions

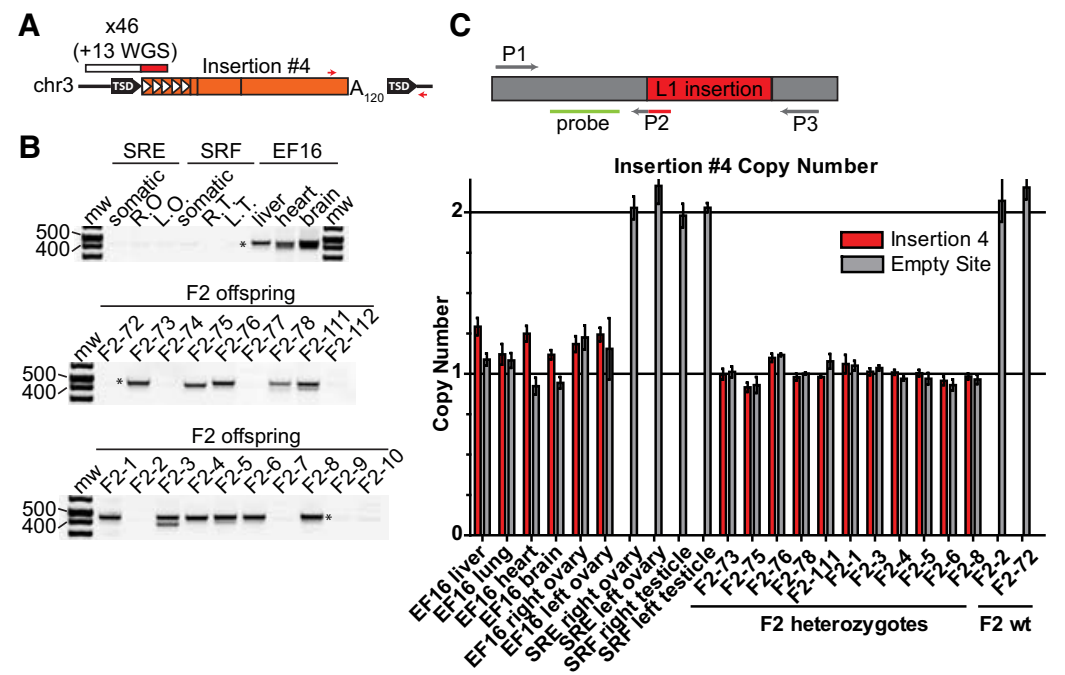

Figure 4. Retrotransposition in the late germline. $(A)$ Diagram of insertion \#4. Features are depicted as in Figure 2A. Red arrows indicate the position of 3' junction genotyping primers. $(B)$ Genotyping panel for insertion \#4. SRE and SRF are P-generation mice, SREF16 is the F1 maternal mouse, and 72-78, 111-112, and 1-10 are the F1 offspring of SREF16 and SRCD14. (Somatic) Mix of liver, heart, and brain genomic DNA; (R.O., L.O.) right ovary, left ovary; (R.T., L.T.) right testicle, left testicle. Variation in size of the $3^{\prime}$ junction genotyping band likely reflects shortening of the poly $(A)$ tract of insertion \#4, as previously reported (Grandi et al. 2013). (C) Prevalence of insertion \#4 among tissues of maternal mouse SREF16. Xaxis, from left: tissues of F1 mouse SREF16, ovaries and testicles of P mice SRE and SRF, liver of $11 \mathrm{~F} 1 \mathrm{mice}$ heterozygous for insertion \#4, and liver of two F1 mice lacking insertion \#4. The average value among the 11 heterozygous F1 mice is set as a copy number of 1 . Data are reported as the mean and standard deviation of three independent qPCR experiments, each comprising four technical replicates per reaction. (Top) Schematic of the probe-based qPCR assay used to quantify insertion \#4 and empty site prevalence. The L1 insertion is shown in red; positions of the forward primer (P1) junction-spanning filled site reverse primer (P2), empty site reverse primer (P3), and hydrolysis probe (green) are indicated. 
A

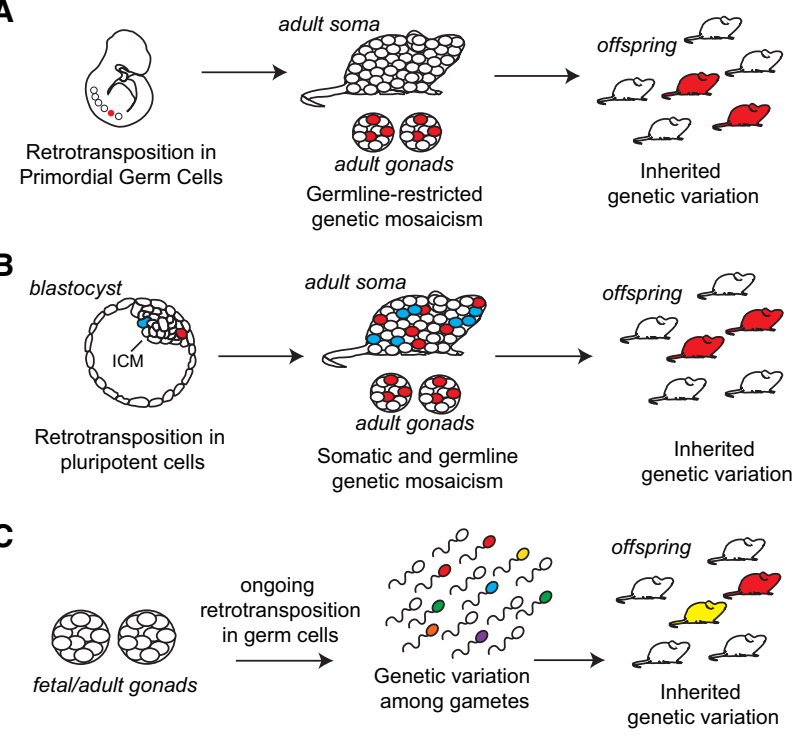

Figure 5. Model for the developmental origins of heritable L1 retrotransposition events. (A) Retrotransposition in the early primordial germline. From left: a retrotransposition event occurring in early PGCs (red) gives rise to germline-restricted genetic mosaicism in the adult animal. The L1 insertion is present in both testes and is heritable by subsequent generations, potentially by multiple F1 siblings. (B) Retrotransposition in the early embryo. Two retrotransposition events in pluripotent cells are indicated (red and blue). The red event contributes to somatic and germ tissues, while the blue event only contributes to somatic tissues in the adult animal. The red insertion is heritable by subsequent generations, potentially by multiple F1 siblings. (C) Retrotransposition in the late germline. Ongoing retrotransposition in adult germ cells, theoretically taking place at any stage from germline stem cells through mature gametes, may generate a large amount of diversity with individual insertions present at low frequency within the gamete pool (multicolored sperm). Each individual insertion has a low probability of contributing to genetic diversity in subsequent generations.

fail to be transmitted. We therefore hypothesize that the early mammalian embryo is a complex mosaic incorporating a constellation of de novo retroelement insertions. We speculate that the contribution of a particular insertion to the germ lineage and ultimately its transmission to the next generation are collectively determined by the dynamics of cell fate specification in the early embryo, random chance, and perhaps whether the insertion has a functional impact on germ cell development and fertility. It is worth noting, for example, that somatic/germline mosaic insertion \#5 exhibited a maximum prevalence of $\sim 1.5 \%$ in the right ovary of mosaic mouse SRE (Fig. 3C) but was transmitted to $4 / 7$ $(\sim 57 \%)$ of her offspring (Figs. 1, 3B; Supplemental Table 2). Thus, early embryonic insertions present at low prevalence in somatic and germ tissues of a parental mouse nevertheless have the potential to contribute substantially to genetic diversity in the next generation, presumably by their fortuitous presence in a subset of germ cells that ultimately give rise to offspring.

In contrast, insertions arising during later germline development (e.g., insertion \#4) may contribute a broad spectrum of genetic diversity to the gamete pool, yet each insertion individually would have a small likelihood of transmission (Fig. 5C). Indeed, our experiments were primarily designed to identify transmitted de novo insertions in heterozygous offspring, and therefore our results may be biased toward early events (germline or embryonic) which ultimately are present in multiple gametes and therefore have a high likelihood of transmission. Thus, while an early embryonic or early PGC retrotransposition event may result in the same insertion being transmitted to multiple siblings, events occurring later in germline development may potentially produce more genetic diversity within a single generation.

De novo heritable L1 retrotransposition is a component of the ongoing evolutionary interplay between retroelements and mammalian genomes, the importance of which is exemplified by recent studies demonstrating the exaptation of LTR retrotransposon sequences and protein products for pluripotency maintenance and embryonic development (Wang et al. 2014; Grow et al. 2015). Furthermore, recent publications have implicated somatic retrotransposition in the brain as a feature of both normal neurobiology and neurological diseases (Muotri et al. 2005, 2010; Coufal et al. 2009, 2011; Baillie et al. 2011; Evrony et al. 2012, 2015; Bundo et al. 2014; Upton et al. 2015; Erwin et al. 2016). Early embryonic insertions contributing broad mosaicism to tissues including the brain likewise represent a component of genetic neurodiversity, and the prevalence and potential functional consequences of such insertions compared to those occurring specifically in cells of the neuronal lineage remain to be determined. Future studies employing single-cell genomic analyses, and other approaches, will likely further elucidate the scope and consequences of ongoing retrotransposition in the mammalian germline and early embryo (Malki et al. 2014).

\section{Methods}

\section{Animals}

All animal breeding and handling procedures were carried out in compliance with the guidelines set forth by the University of Queensland Animal Ethics Committee. To establish breeding pedigrees, adult wild-type C57BL/6J mice were ordered from the University of Queensland Biological Resources Facility (UQ-BRF), which in turn sources animals from the Animal Resources Center (ARC, Western Australia). The UQ-BRF and ARC provided helpful information regarding the source and breeding history of the animals used in this study. The "P-generation" mice used to initiate the breeding pedigrees in this study were no more than 10 generations removed from the Jackson Laboratory C57BL6/J strain.

\section{mRC-seq library construction}

Genomic DNA from animals and tissues of interest was used to construct Illumina libraries for mRC-seq as described in Shukla et al. (2013), except using insert sizes of 450 and $550 \mathrm{bp}$. Illumina libraries were constructed using the Illumina TruSeq DNA LT kit or the Illumina TruSeq Nano DNA LT kit according to the manufacturer's instructions (Illumina). A detailed description of library preparation can be found in Supplemental Methods.

\section{mRC-seq hybridization reactions}

Hybridization reactions were performed as described in Shukla et al. (2013), except using a pool of biotinylated capture probes designed against mouse retrotransposons represented by L1 subfamilies $T_{F} G_{F}$ and $A$, SINEs B1 and B2, and the LTR elements IAP and ETn (Supplemental Table 1). Illumina libraries were pooled to achieve a total mass of $1 \mu \mathrm{g}$ (Supplemental Table 1). A detailed description of mRC-seq hybridization can be found in Supplemental Methods. 


\section{Illumina sequencing and mRC-seq analysis}

We performed mRC-seq on either pooled genomic DNA from somatic tissues representative of the three embryonic germ layers (liver, skeletal or cardiac muscle, and brain) or DNA extracted from tail tips and ear punches (Supplemental Fig. S1B; Supplemental Table 1). We performed $\mathrm{mRC}$-seq on the individual somatic tissues and gonads of mice SRA and SRE and the germ cell fraction of the left and right testicles of SRCD14. We also performed 30x whole-genome sequencing on P-generation animals SRE and SRF, and 22× WGS on their F1 offspring SREF15-SREF21, using pooled somatic tissue genomic DNA (Supplemental Table 1). Across all DNA sequencing libraries, we detected 92.8\%, 97.8\%, and $98.7 \%$ of recent reference genome $\mathrm{L} 1\left(\mathrm{~T}_{\mathrm{F}}, \mathrm{G}_{\mathrm{F}}, \mathrm{A}\right)$, LTR retrotransposon (IAP, ETn), and SINE (B1, B2) insertions, respectively (Supplemental Table 1).

A summary of library pooling and sequencing reads per library is included in Supplemental Table 1. mRC-seq libraries were sequenced on an Illumina HiSeq 2500 platform (Macrogen), generating $2 \times 150$-bp read pairs and $2 \times 250$-bp read pairs. Some libraries were also sequenced on an Illumina MiSeq platform, generating $2 \times 250$-bp and $2 \times 300$-bp read pairs. WGS libraries were sequenced on an Illumina HiSeq 2500 platform (Macrogen), generating $2 \times 250$-bp read pairs. $\mathrm{mRC}$-seq and WGS data were processed as follows: read pairs were first trimmed from their $5^{\prime}$ and $3^{\prime}$ ends to remove any bases with quality $<10$, then assembled into contigs using FLASH (Magoc and Salzberg 2011) and default parameters. Two hundred fifty-mer reads from inserts $>500 \mathrm{bp}$ in length failed to form contigs but were retained and analyzed via the same process applied to contigs. Contigs were aligned to the mouse reference genome (mm10) using SOAP2 (Li et al. 2009) (parameters -M 4 -v 2 -r 1 -p 8). Only uniquely aligned reads were retained, and PCR duplicates were removed if they shared the genomic coordinates of another read. Unmapped reads were then aligned to a set of potentially active mouse retrotransposon consensus sequences obtained from Repbase ( $\mathrm{L} 1 \mathrm{~T}_{\mathrm{F}}, \mathrm{G}_{\mathrm{F}}$, and A subfamilies; SINE B1 and SINE B2; IAP LTR and ETn LTR) (Bao et al. 2015), using LAST (Kielbasa et al. 2011) (parameters -s 2 -l 12 -d $30-\mathrm{q} 3$-e 30). Reads aligned at $>90 \%$ identity to a retrotransposon consensus sequence were retained if the alignment spanned $\geq 33$ nt of one contig end. Reads passing this filter were then aligned to mm10 using LAST and formed into clusters following an existing strategy (Shukla et al. 2013). Clusters with $\geq 3$ reads were then manually inspected for evidence of chimerism and annotated as polymorphic if found in an existing database of mouse polymorphisms (Nellaker et al. 2012) or in all of the libraries from at least one founder animal.

\section{Validation and structural characterization of de novo L1 insertions}

Putative insertions were called as potentially de novo if they appeared in one or more offspring from the same pedigree and were absent from the parental mice. In addition, some insertions were readily detected in offspring and were also detected with 12 reads upon deep sequencing of individual tissues of maternal mice SRA and SRE. Such insertions were treated as potentially de novo and chimeric in the maternal mouse. Reads were then manually inspected using SerialCloner (http://serialbasics.free.fr/ Serial_Cloner.html) and the BLAT tool on the UCSC Genome Browser (Kent 2002). Reads which clearly represented molecular chimeras and those which could not be manually assigned to a specific genomic location due to repeat content were disregarded. For putative insertions passing manual inspection, primers were designed in the putative $5^{\prime}$ and $3^{\prime}$ flanking genomic DNA (Supplemental Table 2). Oligonucleotide primers were ordered from Integrated DNA Technologies (IDT).
Empty-filled validation PCRs were carried out using primers specific to the $5^{\prime}$ and $3^{\prime}$ genomic sequence flanking putative insertions. Validation PCRs for $5^{\prime}$ and $3^{\prime}$ junctions were carried out using the appropriate flanking genomic primer paired with a primer internal to the L1 sequence; where necessary, hemi-nested and fully nested PCR reactions were carried out using appropriately designed genomic and L1-specific primers (Supplemental Table 2). The full details of PCR validation can be found in Supplemental Methods.

\section{Plasmid constructs}

pTN201 (Naas et al. 1998), TGF21 (Goodier et al. 2001), pJM101/ L1.3 (Dombroski et al. 1993; Sassaman et al. 1997), and pJM105/ L1.3 (Wei et al. 2000) were described previously. Descriptions of these constructs can be found in Supplemental Methods.

\section{Generation of mouse $\mathrm{L} 1$ reporter constructs}

Insertion \#1 and insertion \#7 were PCR-amplified using the Roche Expand Long Template PCR system and cloned into retrotransposition indicator vectors using standard molecular biology techniques. Detailed descriptions of the cloning strategies can be found in Supplemental Methods.

\section{Cultured cell retrotransposition assay}

HeLa-JVM cells were seeded at $2 \times 10^{4}$ cells/well in 6-well plates and transfected using FuGENE HD Transfection Reagent (Promega) at a ratio of $3 \mu \mathrm{L}$ to $1 \mu \mathrm{g}$ plasmid DNA. G418 selection $(400 \mu \mathrm{g} / \mathrm{mL})$ was initiated at $72 \mathrm{~h}$ post-transfection and carried out for 10-12 d (Wei et al. 2000).

Assays for transfection efficiency were performed in parallel by cotransfection of pCAG-EGFP with L1 reporter plasmids. At $48 \mathrm{~h}$ post-transfection, cells were subjected to flow cytometry on a Cyan ADP Analyzer (Beckman-Coulter) at the Translational Research Institute Flow Cytometry Core. The percentage of EGFP positive cells for each L1 reporter construct was used to normalize the G418-resistant colony counts obtained in the retrotransposition assay (Wei et al. 2000; Kopera et al. 2016). Full details of the cultured cell retrotransposition assay can be found in Supplemental Methods.

\section{Mosaicism analysis qPCR}

Quantitative PCR using genomic DNA as template was carried out using primers and dual-labeled PrimeTime qPCR probes (5' 6-FAMZEN-3' Iowa Black FQ) from IDT. Control reactions for DNA input were performed using a predesigned PrimeTime qPCR assay for the single-copy mouse gene RPP25 (Mm.PT.58.21641426.g), with a dual-labeled probe (5' 6-FAM ${ }^{\mathrm{TM}}-\mathrm{ZEN}-3^{\prime}$ Iowa Black FQ). Reactions were run on a Roche LightCycler 480 II with the following cycling conditions: $95^{\circ} \mathrm{C}, 5 \mathrm{~min}$, followed by 45 cycles of $95^{\circ} \mathrm{C}$ for $10 \mathrm{sec}$, and $57^{\circ} \mathrm{C}$ for $1 \mathrm{~min}$, then melt curve $\left(0.11^{\circ} \mathrm{C}\right.$ per sec from $57^{\circ} \mathrm{C}$ to $\left.95^{\circ} \mathrm{C}\right) . C_{\mathrm{t}}$ values were calculated on the LightCycler software using absolute quantification 2nd derivative max. Details of mosaicism analysis qPCRs can be found in Supplemental Methods.

\section{Data access}

mRC-seq and WGS data from this study have been submitted to the European Nucleotide Archive (ENA; http://www.ebi.ac.uk/ ena/) under project accession number PRJEB10299. Sanger trace files from this study have been submitted to the NCBI Trace Archive (http://www.ncbi.nlm.nih.gov/Traces/home/index.cgi) with TI numbers TI2344112704-TI234412736 and TI234412752.

\section{Genome Research}

www.genome.org 


\section{Competing interest statement}

J.A.J. is employed by Roche Sequencing Solutions, Inc., and Roche Sequencing Solutions reagents were used in the study.

\section{Acknowledgments}

We thank Dr. John V. Moran for the constructs pJM101/L1.3 and pJM105/L1.3 and for the HeLa-JVM cell line. We thank Dr. John L. Goodier for assistance in providing samples and for helpful discussion. We thank Dr. John V. Moran and Dr. Sara R. Heras for critically reading the manuscript. We thank Ms. Carmen SalvadorPalomeque and Dr. Santiago Morell for helpful contributions and discussion. G.J.F. acknowledges the support of an National Health and Medical Research Council (NHMRC) Research Fellowship (GNT1106214). Work in the Faulkner laboratory was funded by Australian NHMRC Project Grants GNT1042449, GNT1045991, GNT1067983, GNT1068789, and GNT1106206, the Mater Foundation, and the European Union's Seventh Framework Programme (FP7/2007-2013) under grant agreement No. 259743 underpinning the MODHEP consortium. Work in the Kazazian laboratory was funded by an RO1 (1R01GM09987501) and a P50 from the National Institute of General Medical Sciences. Work in the Garcia-Perez laboratory was supported by CICE-FEDER-P12-CTS-2256, Plan Nacional de I+D+I 2008-2011 and Ministerio de Ciencia e Innovación 2013-2016 (FIS-FEDERPI11/01489 and FIS-FEDER-PI14/02152), PCIN-2014-115ERA-NET NEURON II, the European Research Council (ERCConsolidator ERC-STG-2012-233764), by an International Early Career Scientist grant from the Howard Hughes Medical Institute (IECS-55007420), and by The Wellcome Trust-University of Edinburgh Institutional Strategic Support Fund (ISFF2). P.G. was supported by a University of Queensland International Postgraduate Research Scholarship (IPRS) and an Australian Postgraduate Award (APA). F.J.S.-L. was supported by the People Programme (Marie Curie Actions) of the European Union's Seventh Framework Programme (FP7/2007-2013) under REA grant agreement no. PIOF-GA-2013-623324. G.-O.B. was supported by a German Research Foundation (DFG)-Germany postdoctoral fellowship (BO4460/1-1). A.D.E. was supported by an Australian Research Council Discovery Early Career Researcher Award (DE150101117). Author contributions: S.R.R., P.G., D.J.G., F.J.S.-L., G.-O.B., M.M.-L., J.S.J., M.-J.H.C.K., P.E.C., and G.J.F. designed and performed experiments. J.L.G-P., H.H.K., and G.J.F. provided resources. D.J.G., J.A.J., and G.J.F. designed mRC-seq. G.J.F. and A.D.E. performed the bioinformatic analysis. S.R.R. and G.J.F. conceived the study and wrote the manuscript. All authors commented on or contributed to the final manuscript.

\section{References}

Akagi K, Li J, Stephens RM, Volfovsky N, Symer DE. 2008. Extensive variation between inbred mouse strains due to endogenous L1 retrotransposition. Genome Res 18: 869-880.

Akagi K, Stephens RM, Li J, Evdokimov E, Kuehn MR, Volfovsky N, Symer DE. 2010. MouseIndelDB: a database integrating genomic indel polymorphisms that distinguish mouse strains. Nucleic Acids Res 38: D600-D606.

An W, Han JS, Wheelan SJ, Davis ES, Coombes CE, Ye P, Triplett C, Boeke JD. 2006. Active retrotransposition by a synthetic L1 element in mice. Proc Natl Acad Sci 103: 18662-18667.

Aravin AA, Sachidanandam R, Bourc'his D, Schaefer C, Pezic D, Toth KF, Bestor T, Hannon GJ. 2008. A piRNA pathway primed by individual transposons is linked to de novo DNA methylation in mice. Mol Cell 31: 785-799.

Baillie JK, Barnett MW, Upton KR, Gerhardt DJ, Richmond TA, De Sapio F, Brennan PM, Rizzu P, Smith S, Fell M, et al. 2011. Somatic retrotranspo- sition alters the genetic landscape of the human brain. Nature 479: 534-537.

Bao W, Kojima KK, Kohany O. 2015. Repbase Update, a database of repetitive elements in eukaryotic genomes. Mob DNA 6: 11 .

Boissinot S, Entezam A, Young L, Munson PJ, Furano AV. 2004. The insertional history of an active family of L1 retrotransposons in humans. Genome Res 14: 1221-1231.

Bourc'his D, Bestor TH. 2004. Meiotic catastrophe and retrotransposon reactivation in male germ cells lacking Dnmt3L. Nature 431: 96-99.

Branciforte D, Martin SL. 1994. Developmental and cell type specificity of LINE-1 expression in mouse testis: implications for transposition. Mol Cell Biol 14: 2584-2592.

Brouha B, Meischl C, Ostertag E, de Boer M, Zhang Y, Neijens H, Roos D, Kazazian HH Jr. 2002. Evidence consistent with human L1 retrotransposition in maternal meiosis I. Am J Hum Genet 71: 327-336.

Bundo M, Toyoshima M, Okada Y, Akamatsu W, Ueda J, Nemoto-Miyauchi T, Sunaga F, Toritsuka M, Ikawa D, Kakita A, et al. 2014. Increased 11 retrotransposition in the neuronal genome in schizophrenia. Neuron $\mathbf{8 1}$ : 306-313.

Castro-Diaz N, Ecco G, Coluccio A, Kapopoulou A, Yazdanpanah B, Friedli M, Duc J, Jang SM, Turelli P, Trono D. 2014. Evolutionally dynamic L1 regulation in embryonic stem cells. Genes Dev 28: 1397-1409.

Chambers VS, Marsico G, Boutell JM, Di Antonio M, Smith GP, Balasubramanian S. 2015. High-throughput sequencing of DNA Gquadruplex structures in the human genome. Nat Biotechnol 33: 877-881.

Coufal NG, Garcia-Perez JL, Peng GE, Yeo GW, Mu Y, Lovci MT, Morell M, O'Shea KS, Moran JV, Gage FH. 2009. L1 retrotransposition in human neural progenitor cells. Nature 460: 1127-1131.

Coufal NG, Garcia-Perez JL, Peng GE, Marchetto MC, Muotri AR, Mu Y, Carson CT, Macia A, Moran JV, Gage FH. 2011. Ataxia telangiectasia mutated (ATM) modulates long interspersed element-1 (L1) retrotransposition in human neural stem cells. Proc Natl Acad Sci 108: 20382-20387.

Crichton JH, Dunican DS, Maclennan M, Meehan RR, Adams IR. 2014. Defending the genome from the enemy within: mechanisms of retrotransposon suppression in the mouse germline. Cell Mol Life Sci 71: 1581-1605.

Cunliffe P, Reed V, Boyd Y. 2001. Intragenic deletions at Atp7a in mouse models for Menkes disease. Genomics 74: 155-162.

DeBerardinis RJ, Goodier JL, Ostertag EM, Kazazian HH Jr. 1998. Rapid amplification of a retrotransposon subfamily is evolving the mouse genome. Nat Genet 20: 288-290.

Dombroski BA, Scott AF, Kazazian HH Jr. 1993. Two additional potential retrotransposons isolated from a human L1 subfamily that contains an active retrotransposable element. Proc Natl Acad Sci 90: 6513-6517.

Erwin JA, Paquola AC, Singer T, Gallina I, Novotny M, Quayle C, Bedrosian TA, Alves FI, Butcher CR, Herdy JR, et al. 2016. L1-associated genomic regions are deleted in somatic cells of the healthy human brain. Nat Neurosci 19: 1583-1591.

Evrony GD, Cai X, Lee E, Hills LB, Elhosary PC, Lehmann HS, Parker JJ, Atabay KD, Gilmore EC, Poduri A, et al. 2012. Single-neuron sequencing analysis of L1 retrotransposition and somatic mutation in the human brain. Cell 151: 483-496.

Evrony GD, Lee E, Mehta BK, Benjamini Y, Johnson RM, Cai X, Yang L, Haseley P, Lehmann HS, Park PJ, et al. 2015. Cell lineage analysis in human brain using endogenous retroelements. Neuron 85: 49-59.

Fanning TG. 1983. Size and structure of the highly repetitive BAM HI element in mice. Nucleic Acids Res 11: 5073-5091.

Furano AV. 2000. The biological properties and evolutionary dynamics of mammalian LINE-1 retrotransposons. Prog Nucleic Acid Res Mol Biol 64: $255-294$.

Garcia-Perez JL, Marchetto MC, Muotri AR, Coufal NG, Gage FH, O'Shea KS, Moran JV. 2007. LINE-1 retrotransposition in human embryonic stem cells. Hum Mol Genet 16: 1569-1577.

Gasior SL, Preston G, Hedges DJ, Gilbert N, Moran JV, Deininger PL. 2007. Characterization of pre-insertion loci of de novo L1 insertions. Gene 390: 190-198.

Goodier JL, Ostertag EM, Kazazian HH Jr. 2000. Transduction of 3'-flanking sequences is common in L1 retrotransposition. Hum Mol Genet 9: 653-657.

Goodier JL, Ostertag EM, Du K, Kazazian HH Jr. 2001. A novel active L1 retrotransposon subfamily in the mouse. Genome Res 11: 1677-1685.

Grandi FC, Rosser JM, An W. 2013. LINE-1-derived poly(A) microsatellites undergo rapid shortening and create somatic and germline mosaicism in mice. Mol Biol Evol 30: 503-512.

Grow EJ, Flynn RA, Chavez SL, Bayless NL, Wossidlo M, Wesche DJ, Martin L, Ware CB, Blish CA, Chang HY, et al. 2015. Intrinsic retroviral reactivation in human preimplantation embryos and pluripotent cells. Nature 522: 221-225. 
Han JS, Szak ST, Boeke JD. 2004. Transcriptional disruption by the L1 retrotransposon and implications for mammalian transcriptomes. Nature 429: $268-274$.

Hancks DC, Kazazian HH Jr. 2012. Active human retrotransposons: variation and disease. Curr Opin Genet Dev 22: 191-203.

Hardies SC, Wang L, Zhou L, Zhao Y, Casavant NC, Huang S. 2000. LINE-1 (L1) lineages in the mouse. Mol Biol Evol 17: 616-628.

Holmes SE, Dombroski BA, Krebs CM, Boehm CD, Kazazian HH Jr. 1994. A new retrotransposable human L1 element from the LRE2 locus on chromosome 1q produces a chimaeric insertion. Nat Genet 7: 143-148.

Jurka J. 1997. Sequence patterns indicate an enzymatic involvement in integration of mammalian retroposons. Proc Natl Acad Sci 94: 1872-1877.

Kano H, Godoy I, Courtney C, Vetter MR, Gerton GL, Ostertag EM, Kazazian HH Jr. 2009. L1 retrotransposition occurs mainly in embryogenesis and creates somatic mosaicism. Genes Dev 23: 1303-1312.

Kazazian HH Jr. 2000. Genetics. L1 retrotransposons shape the mammalian genome. Science 289: 1152-1153.

Kazazian HH Jr, Moran JV. 1998. The impact of L1 retrotransposons on the human genome. Nat Genet 19: 19-24.

Kazazian HH Jr, Wong C, Youssoufian H, Scott AF, Phillips DG, Antonarakis SE. 1988. Haemophilia A resulting from de novo insertion of L1 sequences represents a novel mechanism for mutation in man. Nature 332: 164-166.

Keane TM, Goodstadt L, Danecek P, White MA, Wong K, Yalcin B, Heger A, Agam A, Slater G, Goodson M, et al. 2011. Mouse genomic variation and its effect on phenotypes and gene regulation. Nature 477: 289-294.

Kent WJ. 2002. BLAT-the BLAST-like alignment tool. Genome Res 12: 656-664.

Kielbasa SM, Wan R, Sato K, Horton P, Frith MC. 2011. Adaptive seeds tame genomic sequence comparison. Genome Res 21: 487-493.

Kimberland ML, Divoky V, Prchal J, Schwahn U, Berger W, Kazazian HH Jr. 1999. Full-length human L1 insertions retain the capacity for high frequency retrotransposition in cultured cells. Hum Mol Genet 8: 1557-1560.

Kingsmore SF, Giros B, Suh D, Bieniarz M, Caron MG, Seldin MF. 1994. Glycine receptor $\beta$-subunit gene mutation in spastic mouse associated with LINE-1 element insertion. Nat Genet 7: 136-141.

Klawitter S, Fuchs NV, Upton KR, Munoz-Lopez M, Shukla R, Wang J, Garcia-Canadas M, Lopez-Ruiz C, Gerhardt DJ, Sebe A, et al. 2016 Reprogramming triggers endogenous L1 and Alu retrotransposition in human induced pluripotent stem cells. Nat Commun 7: 10286.

Kohrman DC, Harris JB, Meisler MH. 1996. Mutation detection in the med and medJ alleles of the sodium channel Scn8a. Unusual splicing due to a minor class AT-AC intron. J Biol Chem 271: 17576-17581.

Kopera HC, Larson PA, Moldovan JB, Richardson SR, Liu Y, Moran JV. 2016. LINE-1 cultured cell retrotransposition assay. Methods Mol Biol 1400: 139-156.

Lei L, Spradling AC. 2013. Mouse primordial germ cells produce cysts that partially fragment prior to meiosis. Development 140: 2075-2081.

Li R, Yu C, Li Y, Lam TW, Yiu SM, Kristiansen K, Wang J. 2009. SOAP2: an improved ultrafast tool for short read alignment. Bioinformatics 25: 1966-1967.

Li J, Akagi K, Hu Y, Trivett AL, Hlynialuk CJ, Swing DA, Volfovsky N, Morgan TC, Golubeva Y, Stephens RM, et al. 2012. Mouse endogenous retroviruses can trigger premature transcriptional termination at a distance. Genome Res 22: 870-884.

Loeb DD, Padgett RW, Hardies SC, Shehee WR, Comer MB, Edgell MH, Hutchison CA III. 1986. The sequence of a large L1Md element reveals a tandemly repeated $5^{\prime}$ end and several features found in retrotransposons. Mol Cell Biol 6: 168-182.

Luan DD, Korman MH, Jakubczak JL, Eickbush TH. 1993. Reverse transcription of R2Bm RNA is primed by a nick at the chromosomal target site: a mechanism for non-LTR retrotransposition. Cell 72: 595-605.

Macfarlane CM, Collier P, Rahbari R, Beck CR, Wagstaff JF, Igoe S, Moran JV, Badge RM. 2013. Transduction-specific ATLAS reveals a cohort of highly active L1 retrotransposons in human populations. Hum Mutat 34: 974-985.

Mager DL, Stoye JP. 2015. Mammalian endogenous retroviruses. Microbiol Spectr 3: MDNA3-0009-2014.

Magoc T, Salzberg SL. 2011. FLASH: fast length adjustment of short reads to improve genome assemblies. Bioinformatics 27: 2957-2963.

Maksakova IA, Romanish MT, Gagnier L, Dunn CA, van de Lagemaat LN, Mager DL. 2006. Retroviral elements and their hosts: insertional mutagenesis in the mouse germ line. PLoS Genet 2: e2.

Malki S, van der Heijden GW, O’Donnell KA, Martin SL, Bortvin A. 2014. A role for retrotransposon LINE-1 in fetal oocyte attrition in mice. Dev Cell 29: 521-533.

Martin SL, Branciforte D. 1993. Synchronous expression of LINE-1 RNA and protein in mouse embryonal carcinoma cells. Mol Cell Biol 13: 5383-5392.
Moran JV, Holmes SE, Naas TP, DeBerardinis RJ, Boeke JD, Kazazian HH Jr. 1996. High frequency retrotransposition in cultured mammalian cells. Cell 87: 917-927.

Moran JV, DeBerardinis RJ, Kazazian HH Jr. 1999. Exon shuffling by L1 retrotransposition. Science 283: 1530-1534.

Mulhardt C, Fischer M, Gass P, Simon-Chazottes D, Guenet JL, Kuhse J, Betz H, Becker CM. 1994. The spastic mouse: aberrant splicing of glycine receptor $\beta$ subunit mRNA caused by intronic insertion of L1 element. Neuron 13: 1003-1015.

Muotri AR, Chu VT, Marchetto MC, Deng W, Moran JV, Gage FH. 2005. Somatic mosaicism in neuronal precursor cells mediated by L1 retrotransposition. Nature 435: 903-910.

Muotri AR, Marchetto MC, Coufal NG, Oefner R, Yeo G, Nakashima K, Gage FH. 2010. L1 retrotransposition in neurons is modulated by MeCP2 Nature 468: 443-446.

Naas TP, DeBerardinis RJ, Moran JV, Ostertag EM, Kingsmore SF, Seldin MF, Hayashizaki Y, Martin SL, Kazazian HH. 1998. An actively retrotransposing, novel subfamily of mouse L1 elements. EMBO J 17: 590-597.

Nellaker C, Keane TM, Yalcin B, Wong K, Agam A, Belgard TG, Flint J, Adams DJ, Frankel WN, Ponting CP. 2012. The genomic landscape shaped by selection on transposable elements across 18 mouse strains. Genome Biol 13: R45.

Ostertag EM, DeBerardinis RJ, Goodier JL, Zhang Y, Yang N, Gerton GL, Kazazian HH Jr. 2002. A mouse model of human L1 retrotransposition. Nat Genet 32: 655-660.

Padgett RW, Hutchison CA III, Edgell MH. 1988. The F-type $5^{\prime}$ motif of mouse L1 elements: a major class of L1 termini similar to the A-type in organization but unrelated in sequence. Nucleic Acids Res 16: 739-749.

Perou CM, Pryor RJ, Naas TP, Kaplan J. 1997. The bg allele mutation is due to a LINE1 element retrotransposition. Genomics 42: 366-368.

Petryszak R, Keays M, Tang YA, Fonseca NA, Barrera E, Burdett T, Fullgrabe A Fuentes AM, Jupp S, Koskinen S, et al. 2016. Expression Atlas update-an integrated database of gene and protein expression in humans, animals and plants. Nucleic Acids Res 44: D746-D752.

Pickeral OK, Makalowski W, Boguski MS, Boeke JD. 2000. Frequent human genomic DNA transduction driven by LINE-1 retrotransposition. Genome Res 10: 411-415.

Picollo A, Malvezzi M, Accardi A. 2015. TMEM16 proteins: unknown structure and confusing functions. J Mol Biol 427: 94-105.

Quinlan AR, Clark RA, Sokolova S, Leibowitz ML, Zhang Y, Hurles ME, Mell JC, Hall IM. 2010. Genome-wide mapping and assembly of structural variant breakpoints in the mouse genome. Genome Res 20: 623-635.

Quinlan AR, Boland MJ, Leibowitz ML, Shumilina S, Pehrson SM, Baldwin KK, Hall IM. 2011. Genome sequencing of mouse induced pluripotent stem cells reveals retroelement stability and infrequent DNA rearrangement during reprogramming. Cell Stem Cell 9: 366-373.

Richardson SR, Doucet AJ, Kopera HC, Moldovan JB, Garcia-Perez JL, Moran JV. 2015. The influence of LINE-1 and SINE retrotransposons on mammalian genomes. Microbiol Spectr 3: MDNA3-0061-2014.

Rowe HM, Jakobsson J, Mesnard D, Rougemont J, Reynard S, Aktas T, Maillard PV, Layard-Liesching H, Verp S, Marquis J, et al. 2010. KAP1 controls endogenous retroviruses in embryonic stem cells. Nature 463: 237-240.

Sassaman DM, Dombroski BA, Moran JV, Kimberland ML, Naas TP, DeBerardinis RJ, Gabriel A, Swergold GD, Kazazian HH Jr. 1997. Many human L1 elements are capable of retrotransposition. Nat Genet 16: $37-43$.

Scott AF, Schmeckpeper BJ, Abdelrazik M, Comey CT, O'Hara B, Rossiter JP, Cooley T, Heath P, Smith KD, Margolet L. 1987. Origin of the human L1 elements: proposed progenitor genes deduced from a consensus DNA sequence. Genomics 1: 113-125.

Shukla R, Upton KR, Munoz-Lopez M, Gerhardt DJ, Fisher ME, Nguyen T, Brennan PM, Baillie JK, Collino A, Ghisletti S, et al. 2013. Endogenous retrotransposition activates oncogenic pathways in hepatocellular carcinoma. Cell 153: 101-111.

Singer MF, Thayer RE, Grimaldi G, Lerman MI, Fanning TG. 1983. Homology between the KpnI primate and BamH1 (M1F-1) rodent families of long interspersed repeated sequences. Nucleic Acids Res 11: 5739-5745.

Sookdeo A, Hepp CM, McClure MA, Boissinot S. 2013. Revisiting the evolution of mouse LINE-1 in the genomic era. Mob DNA 4: 3

Soper SF, van der Heijden GW, Hardiman TC, Goodheart M, Martin SL, de Boer P, Bortvin A. 2008. Mouse maelstrom, a component of nuage, is essential for spermatogenesis and transposon repression in meiosis. Dev Cell 15: 285-297.

Soriano P, Jaenisch R. 1986. Retroviruses as probes for mammalian development: allocation of cells to the somatic and germ cell lineages. Cell 46: 19-29.

\section{Genome Research}

www.genome.org 
Szak ST, Pickeral OK, Makalowski W, Boguski MS, Landsman D, Boeke JD. 2002. Molecular archeology of L1 insertions in the human genome. Genome Biol 3: research0052.

Takahara T, Ohsumi T, Kuromitsu J, Shibata K, Sasaki N, Okazaki Y, Shibata H, Sato S, Yoshiki A, Kusakabe M, et al. 1996. Dysfunction of the Orleans reeler gene arising from exon skipping due to transposition of a fulllength copy of an active L1 sequence into the skipped exon. Hum Mol Genet 5: 989-993.

Trelogan SA, Martin SL. 1995. Tightly regulated, developmentally specific expression of the first open reading frame from LINE-1 during mouse embryogenesis. Proc Natl Acad Sci 92: 1520-1524.

Upton KR, Gerhardt DJ, Jesuadian JS, Richardson SR, Sanchez-Luque FJ, Bodea GO, Ewing AD, Salvador-Palomeque C, van der Knaap MS Brennan PM, et al. 2015. Ubiquitous L1 mosaicism in hippocampal neurons. Cell 161: 228-239.

van den Hurk JA, Meij IC, Seleme MC, Kano H, Nikopoulos K, Hoefsloot LH, Sistermans EA, de Wijs IJ, Mukhopadhyay A, Plomp AS, et al. 2007. L1 retrotransposition can occur early in human embryonic development. Hum Mol Genet 16: 1587-1592.

Wang J, Xie G, Singh M, Ghanbarian AT, Rasko T, Szvetnik A, Cai H, Besser D, Prigione A, Fuchs NV, et al. 2014. Primate-specific endogenous retrovirus-driven transcription defines naive-like stem cells. Nature 516: 405-409.

Watanabe T, Takeda A, Tsukiyama T, Mise K, Okuno T, Sasaki H, Minami N, Imai H. 2006. Identification and characterization of two novel classes of small RNAs in the mouse germline: retrotransposon-derived siRNAs in oocytes and germline small RNAs in testes. Genes Dev 20: 1732-1743.

Watanabe T, Totoki Y, Toyoda A, Kaneda M, Kuramochi-Miyagawa S, Obata Y, Chiba H, Kohara Y, Kono T, Nakano T, et al. 2008. Endogenous
siRNAs from naturally formed dsRNAs regulate transcripts in mouse oocytes. Nature 453: 539-543.

Waterston RH, Lindblad-Toh K, Birney E, Rogers J, Abril JF, Agarwal P, Agarwala R, Ainscough R, Alexandersson M, An P, et al. 2002. Initial sequencing and comparative analysis of the mouse genome. Nature $\mathbf{4 2 0}$ : 520-562.

Wei W, Morrish TA, Alisch RS, Moran JV. 2000. A transient assay reveals that cultured human cells can accommodate multiple LINE-1 retrotransposition events. Anal Biochem 284: 435-438.

Wissing S, Montano M, Garcia-Perez JL, Moran JV, Greene WC. 2011. Endogenous APOBEC3B restricts LINE-1 retrotransposition in transformed cells and human embryonic stem cells. J Biol Chem 286: 36427-36437.

Wissing S, Munoz-Lopez M, Macia A, Yang Z, Montano M, Collins W, Garcia-Perez JL, Moran JV, Greene WC. 2012. Reprogramming somatic cells into iPS cells activates LINE-1 retroelement mobility. Hum $\mathrm{Mol}$ Genet 21: 208-218.

Yajima I, Sato S, Kimura T, Yasumoto K, Shibahara S, Goding CR, Yamamoto H. 1999. An L1 element intronic insertion in the black-eyed white (Mitf [mi-bw]) gene: the loss of a single Mitf isoform responsible for the pigmentary defect and inner ear deafness. Hum Mol Genet 8: 1431-1441.

Yoder JA, Walsh CP, Bestor TH. 1997. Cytosine methylation and the ecology of intragenomic parasites. Trends Genet 13: 335-340.

Zamudio N, Bourc'his D. 2010. Transposable elements in the mammalian germline: a comfortable niche or a deadly trap? Heredity 105: 92-104.

Received December 4, 2016; accepted in revised form May 2, 2017. 


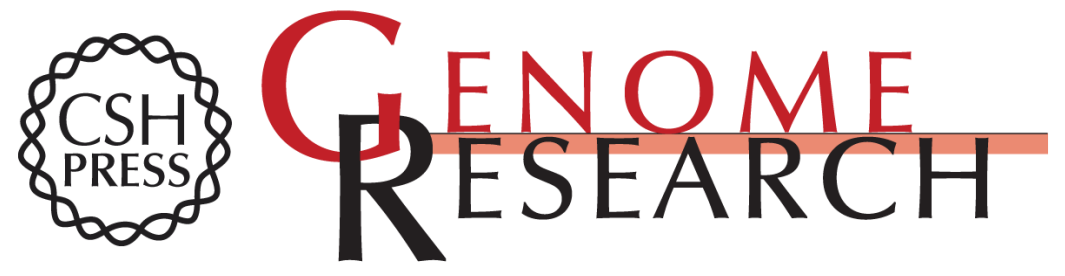

\section{Heritable L1 retrotransposition in the mouse primordial germline and early embryo}

Sandra R. Richardson, Patricia Gerdes, Daniel J. Gerhardt, et al.

Genome Res. 2017 27: 1395-1405 originally published online May 8, 2017

Access the most recent version at doi:10.1101/gr.219022.116

Supplemental Material

References

Open Access

Creative Commons

License

Email Alerting Service
http://genome.cshlp.org/content/suppl/2017/06/28/gr.219022.116.DC1

This article cites 97 articles, 25 of which can be accessed free at: http://genome.cshlp.org/content/27/8/1395.full.html\#ref-list-1

Freely available online through the Genome Research Open Access option.

This article, published in Genome Research, is available under a Creative Commons License (Attribution 4.0 International), as described at http://creativecommons.org/licenses/by/4.0/.

Receive free email alerts when new articles cite this article - sign up in the box at the top right corner of the article or click here.

\section{Affordable, Accurate Sequencing.}

